\title{
ANALISIS PENENTUAN LOKASI BASIS PERIKANAN TERI DAN JALUR PEMASARANNYA DI PROVINSI BANTEN
}

\section{Analysis of Determining the Base Location of Anchovy Fisheries and its Marketing Distribution in The Banten Province}

\author{
*Ririn Irnawati ${ }^{1}$, Dini Surilayani ${ }^{1}$, Adi Susanto', Ani Rahmawati', Aris Munandar ${ }^{1}$, \\ Ratu Sari Mardiah², dan Hery Sutrawan Nurdin ${ }^{1}$ \\ ${ }^{1}$ Universitas Sultan Ageng Tirtayasa \\ Jl. Raya Jkt Km 4 Kota Serang, Banten 42124 Jawa Barat, Indonesia \\ ${ }^{2}$ Politeknik Kelautan dan Perikanan Dumai \\ Jl. Wan Amir No. 1, Kel. Pangkalan Sesai, Prov. Riau, Kota Dumai, Riau, Indonesia \\ Diterima tanggal: 8 Agustus 2019 Diterima setelah perbaikan: 2 Desember 2020 \\ Disetujui terbit: 23 Desember 2020
}

\begin{abstract}
ABSTRAK
Provinsi Banten memiliki lokasi yang strategis dan potensi sumber daya ikan yang besar. Salah satu jenis sumber daya ikan yang produksinya cukup tinggi dan memiliki nilai ekonomis tinggi adalah ikan teri. Produksi ikan teri di Provinsi Banten pada tahun 2015 berkisar 6.474,5 ton atau sebesar $28 \%$ dari produksi ikan pelagis kecil dan $14 \%$ dari produksi total ikan laut. Jumlah produksi ikan teri yang cukup tinggi ini dapat bermanfaat untuk mendukung pengembangan dan pembangunan daerah maupun nasional. Penelitian ini bertujuan untuk menentukan lokasi basis perikanan teri dan memetakan jalur pemasarannya di Provinsi Banten. Penelitian dilakukan di Kabupaten Pandeglang, Kabupaten Lebak, Kabupaten Tangerang, Kabupaten Serang, Kota Serang dan Kota Cilegon, dari Februari hingga November 2017. Penelitian dilakukan dengan menggunakan metode survei dan skoring terhadap kriteria yang ditetapkan. Data jalur pemasaran ikan teri dianalisis secara deskriptif. Berdasarkan hasil skoring, lokasi potensial basis perikanan teri di Provinsi Banten adalah Pandeglang, Kab. Serang, Kota Serang dan Kota Cilegon. Berdasarkan nilai LQ, Kabupaten Pandeglang bukan merupakan wilayah basis produksi teri. Namun, berdasarkan hasil survei diperoleh data dan informasi bahwa pusat pendaratan dan pengolahan teri dengan volume produksi tinggi dan kontinu sepanjang tahun berada di sepanjang pesisir Selat Sunda yaitu mulai dari Kecamatan Panimbang, Citeureup hingga Sumur. Jalur distribusi pemasaran ikan teri yang terdapat di Banten adalah jenis saluran tingkat dua dan saluran tingkat tiga. Saluran tingkat dua yaitu produsen-pengepul-pengecer-konsumen, mempunyai dua perantara penjualan. Pada pasar konsumen, mereka merupakan grosir atau pedagang besar dan sekaligus pengecer. Saluran tingkat tiga terdiri dari produsen-pengepul-pengecer-distributor-konsumen yang mempunyai tiga perantara penjualan.
\end{abstract}

Kata Kunci: jalur pemasaran; lokasi basis; Banten; pemasaran; teri

\begin{abstract}
Banten has strategic location and abundant fisheries resources. The anchovy is one of the largest fish resources in terms of production and economic value. Its production came out to about 3,972.1 tons or $22.2 \%$ of small pelagic fish production and $14 \%$ of total marine fish production. The production of anchovy is highly beneficial to support both regional and national development. This research aimed at mapping potential location of anchovy and its marketing line in Banten Province. The research was conducted at Pandeglang Regency, Lebak Regency, Tangerang Regency, Serang Regency, Serang and Cilegon from February to November 2017 with survey and scoring method. Data regarding the marketing channel of anchovy were analyzed descriptively. The scoring results showed that the potential location of anchovy fisheries in Banten Province were based in Pandeglang, Serang Regency, Serang and Cilegon. Based on LQ value, Pandeglang Regency was not an anchovy production base area. However, the survey resulted in a data and information that the anchovy landing and processing center with high and continuous production volumes throughout the year were located along the Sunda Strait strating from Panimbang, Citerureup to Sumur subdistrict. Marketing distribution channel for anchovy in Banten were second level and third level channels. The second tier channel were producer-wholesalerretailer-consumer which has two seller. In the consumer market, they were wholesalers and retailers. The third tier channel consisted of producer-wholesaler-retailer-distributor-consumer who had three sales intermediaries.
\end{abstract}

Keywords: marketing channel; base location; Banten; scoring method; anchovy 


\section{PENDAHULUAN}

Provinsi Banten memiliki empat kabupaten dan empat kota yang memiliki wilayah pesisir, dengan panjang garis pantai mencapai 499,62 km (DKP Provinsi Banten, 2018). Banten memiliki potensi sumber daya perikanan yang cukup melimpah, dengan posisi yang sangat strategis. Daerah penangkapan ikan di Banten memiliki karakteristik oseanografi yang unik karena berbatasan langsung dengan Laut Jawa di bagian utara, Samudera Hindia di wilayah selatan serta percampuran massa air keduanya di Selat Sunda pada bagian barat. Kondisi tersebut menjadikan wilayah perairan Provinsi Banten menjadi pusat aktivitas penangkapan ikan baik bagi nelayan setempat maupun nelayan dari wilayah di sekitar Banten (Susanto, 2015; Susanto, Irnawati, Mustahal \& Syabana 2017). Kelompok sumber daya ikan yang cukup melimpah jumlahnya adalah ikan pelagis kecil dengan volume produksi tahun 2015 mencapai $22.855,7$ ton atau sebesar $48,8 \%$ dari produksi total ikan yang ada (DKP Provinsi Banten, 2017).

Salah satu jenis ikan pelagis kecil ekonomis tinggi yang berkontribusi besar terhadap total volume produksi adalah ikan teri. Penangkapan ikan teri di Provinsi Banten dilakukan dengan alat tangkap mini purse seine, bagan apung dan bagan tancap (Susanto, Irnawati, Mustahal \& Syabana, 2017). Produksi ikan yang umumnya ditangkap dengan alat tangkap bagan (lift net) ini pada tahun 2015 mencapai $6.474,5$ ton atau sebesar $28 \%$ dari produksi ikan pelagis kecil dan 14\% dari produksi total ikan laut (DKP Provinsi Banten, 2017). Jumlah produksi sesungguhnya diduga lebih tinggi dari angka tersebut dikarenakan beberapa hal, diantaranya nelayan bagan umumnya tidak mendaratkan ikannya di tempat pelelangan ikan, atau menjual hasil tangkapan teri langsung di tengah laut kepada langgan atau palele (pengepul/pengumpul/juragan) sehingga tidak seluruhnya tercatat di pelabuhan perikanan. Padahal data yang akurat sangat penting bagi para pemangku kepentingan dalam menyusun dan menetapkan strategi serta kebijakan pengembangan perikanan teri untuk kesejahteraan nelayan di Provinsi Banten.

Irnawati, Mustahal, Susanto \& Syabana (2014 dan 2015) menyatakan bahwa perikanan bagan untuk penangkapan ikan teri dapat dikembangkan menjadi perikanan tangkap yang ramah lingkungan. Peraturan Menteri Kelautan dan Perikanan (Permen KP) No. 2 Tahun 2015 tentang Larangan Penggunaan Alat Penangkapan Ikan Pukat Hela (Trawl) dan Pukat Tarik (Seine nets) di Wilayah Pengelolaan Perikanan Republik Indonesia (WPP RI) memberikan dampak positif terhadap peningkatan produksi ikan teri, tidak terkecuali di Banten. Hal ini juga berpengaruh terhadap meningkatnya aktivitas usaha pengolahan ikan teri yang dilakukan di sekitar pusat pendaratan ikan dalam bentuk teri asin. Ikan teri merupakan salah satu komoditas perikanan yang bernilai ekonomis tinggi dan menjadi komoditas industri pengolahan produk perikanan di berbagai wilayah pesisir nusantara (Laisa, Sayekti \& Nugraha, 2013; Safruddin, Zainuddin \& Tresnati, 2014; Akbar, Diansyah \& Isnaini, 2016; Sutono \& Susanto, 2016). Namun keterbatasan pengetahuan dan minimnya inovasi menyebabkan pengolahan ikan teri di Provinsi Banten belum berkembang sehingga nilai tambah ekonomi yang dinikmati oleh nelayan belum optimal.

Usaha perikanan teri di Banten hampir ditemui di seluruh pesisir Banten, dari Tangerang hingga Pandeglang. Namun informasi mengenai kegiatan penangkapan dan pengolahan serta pemasarannya masih sangat terbatas. Hal ini dipengaruhi pula oleh kegiatan penangkapan teri yang tidak mendaratkan ikannya di pelabuhan perikanan. Padahal informasi mengenai basis lokasi komoditas perikanan sangat bermanfaat untuk meningkatkan produktivitas, daya saing dan kontribusi sektor perikanan terhadap pengembangan suatu wilayah (Lubis, 2011; Husein, Sunindyo, Bahawares, Nainggolan \& Akbar (2015). Selain itu, informasi basis komoditas perikanan juga bermanfaat dalam penyusunan program dan kebijakan bagi pemerintah daerah dalam memanfaatkan sumber daya perikanan secara optimal (Sirait, 2013; Rahmawati, Suryono \& Siswidiyanto, 2014). Penelitian ini bertujuan untuk menentukan lokasi basis perikanan teri di Provinsi Banten dan memetakan jalur pemasaran ikan teri di Provinsi Banten. Penelitian ini diharapkan dapat memberikan informasi mengenai lokasi basis perikanan teri dan jalur pemasarannya kepada pelaku usaha dan pihak terkait sehingga memudahkan dalam melakukan pengelolaan dan pengembangan perikanan teri, serta kemudahan dalam pembinaan para pelaku usaha perikanan teri. 


\section{METODOLOGI}

\section{Lokasi dan Waktu Penelitian}

Penelitian dilakukan pada bulan FebruariSeptember 2017 di pusat-pusat pendaratan ikan dan usaha pengolahan ikan teri yang ada di Provinsi Banten, yaitu Kabupaten Pandeglang, Kabupaten Lebak, Kabupaten Tangerang, Kabupaten Serang, Kota Serang, dan Kota Cilegon. Pemilihan enam kabupaten/kota tersebut karena merupakan wilayah yang memiliki kegiatan perikanan teri, baik usaha penangkapan, pengolahan dan pemasarannya. Peta lokasi penelitian disajikan pada Gambar 1.

\section{Jenis dan Metode Pengambilan Data}

Penelitian ini dilakukan dengan metode survei. Pengumpulan data penelitian dilakukan melalui observasi, wawancara dan studi pustaka. Data primer dan sekunder digunakan dalam penelitian ini. Data primer meliputi harga ikan teri (di tingkat nelayan, di tingkat bakul, di tingkat konsumen), jumlah produksi ikan teri, jumlah dan jenis alat tangkap yang digunakan untuk menangkap ikan teri, lokasi distribusi ikan teri, jalur distribusi dan pemasaran ikan teri. Data sekunder diperoleh melalui studi pustaka, meliputi data time series volume dan nilai produksi ikan teri, volume dan nilai produksi ikan pelagis kecil, volume dan nilai produksi ikan di tingkat provinsi, volume dan nilai produksi ikan di tingkat kabupaten/kota, jumlah nelayan, dan jumlah upaya atau unit penangkapan teri.
Responden dalam penelitian ini berjumlah 72 orang yang meliputi pegawai pelabuhan perikanan atau tempat pelelangan ikan; nelayan penangkap teri; pengepul ikan teri; dan pengolah ikan teri. Responden dipilih secara purposive sampling, yaitu pihak-pihak sebagai pelaku usaha perikanan teri serta yang dianggap paling tahu mengenai perikanan teri di lokasi penelitian.

\section{Metode Analisis Data}

Penentuan lokasi basis perikanan teri dilakukan berdasarkan hasil survei lapang dan skoring terhadap kriteria yang ditetapkan. Kriteria yang digunakan adalah nilai $L Q$, volume produksi, trend volume produksi, nilai produksi, tren nilai produksi, jumlah nelayan, jumlah unit penangkapan teri dan ketersediaan usaha pengolahan teri. Kriteria dan skala penilaian untuk skoring disajikan pada Tabel 1.

Jika suatu lokasi mendapatkan skor nilai $<$ 12, maka lokasi tersebut kurang potensial sebagai lokasi perikanan teri, jika skor nilai berkisar 12-19 maka lokasi tersebut potensial dan jika skor nilai $>20$ maka lokasi tersebut sangat potensial. Jalur pemasaran dan distribusi ikan teri ditentukan berdasarkan hasil wawancara dengan responden yang terdiri atas nelayan, bakul (pengumpul/ langgan/palele), pengolah, pedagang, pengelola tempat pendaratan ikan (pelabuhan perikanan) dan konsumen. Data mengenai distribusi dan pemasaran ikan teri tersebut dianalisis secara deskriptif dan disajikan dalam bentuk peta jalur pemasaran dan distribusi ikan teri.

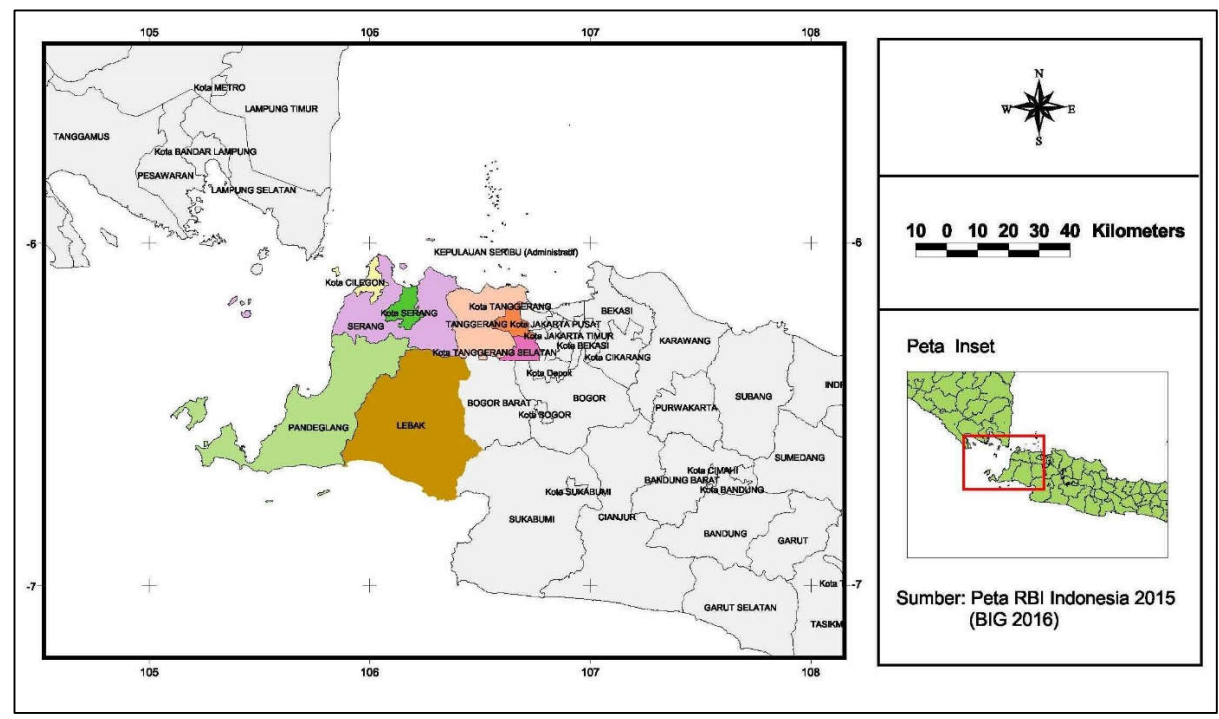

Gambar 1. Peta Lokasi Penelitian.

Picture 1. Map of Research Location.

Sumber: Hasil penelitian, 2017./Source: Research results, 2017. 
Tabel 1. Skala Penilaian Lokasi Basis Perikanan Teri.

Table 1. Scoring Scale of Basis Location of Anchovy Fisheries.

\begin{tabular}{|c|c|c|c|c|}
\hline No. & $\begin{array}{c}\text { Aspek Penilaian/ } \\
\text { Assessment Aspect }\end{array}$ & $\begin{array}{c}\text { Skala Penilaian/ } \\
\text { Scoring Scale }\end{array}$ & $\begin{array}{l}\text { Jenis Datal } \\
\text { Data Type }\end{array}$ & $\begin{array}{l}\text { Sumber Datal } \\
\text { Data Source }\end{array}$ \\
\hline 1. & $\begin{array}{l}\text { Rata-rata nilai } L Q \\
\text { dalam } 5 \text { tahun } \\
\text { (Average } L Q \text { Value in } \\
5 \text { years) }\end{array}$ & $\begin{array}{l}1=L Q<0.5 \\
2=L Q 0.5-<1 \\
3=L Q>1\end{array}$ & $\begin{array}{l}\text { - Produksi teri (Anchovy } \\
\text { production) } \\
\text { - Produksi total (Total } \\
\text { production) }\end{array}$ & $\begin{array}{l}\text { Statistik DKP Banten } \\
\text { (Statistic of Marine } \\
\text { and Fisheries Agency } \\
\text { of Banten) }\end{array}$ \\
\hline 2. & $\begin{array}{l}\text { Rata-rata volume } \\
\text { produksi (Average } \\
\text { production volume) } \\
(\%)\end{array}$ & $\begin{array}{l}1=<35 \\
2=35-<70 \\
3=>70\end{array}$ & $\begin{array}{l}\text { Produksi ikan teri selama } \\
5 \text { tahun (Anchovy } \\
\text { production in } 5 \text { years) }\end{array}$ & $\begin{array}{l}\text { Statistik DKP Banten } \\
\text { (Statistic of Marine } \\
\text { and Fisheries Agency } \\
\text { of Banten) }\end{array}$ \\
\hline 3. & $\begin{array}{l}\text { Tren volume produksi } \\
\text { (Production volume } \\
\text { trends) }\end{array}$ & $\begin{array}{l}1=\text { Turun } / \text { Decreasing } \\
2=\text { Berfluktuasi/Fluctuating } \\
3=\text { Naik/Increasing }\end{array}$ & $\begin{array}{l}\text { Produksi ikan teri selama } \\
5 \text { tahun (Anchovy } \\
\text { production in } 5 \text { years) }\end{array}$ & $\begin{array}{l}\text { Statistik DKP Banten } \\
\text { (Statistic of Marine } \\
\text { and Fisheries Agency } \\
\text { of Banten) }\end{array}$ \\
\hline 4. & $\begin{array}{l}\text { Rata-rata nilai } \\
\text { produksi (Average } \\
\text { production value) }(\%)\end{array}$ & $\begin{array}{l}1=<35 \\
2=35-<70 \\
3=>70\end{array}$ & $\begin{array}{l}\text { Nilai produksi ikan teri } \\
\text { selama } 5 \text { tahun (Anchovy } \\
\text { production value in } 5 \\
\text { years) }\end{array}$ & $\begin{array}{l}\text { Statistik DKP Banten } \\
\text { (Statistic of Marine } \\
\text { and Fisheries Agency } \\
\text { of Banten) }\end{array}$ \\
\hline 5. & $\begin{array}{l}\text { Tren nilai produksi } \\
\text { (Production value } \\
\text { trends) }\end{array}$ & $\begin{array}{l}1=\text { Turun } / \text { Decreasing } \\
2=\text { Berfluktuasi/Fluctuating } \\
3=\text { Naik/Increasing }\end{array}$ & $\begin{array}{l}\text { Nilai produksi ikan teri } \\
\text { selama } 5 \text { tahun (Anchovy } \\
\text { production value in } 5 \\
\text { years) }\end{array}$ & $\begin{array}{l}\text { Statistik DKP Banten } \\
\text { (Statistic of Marine } \\
\text { and Fisheries Agency } \\
\text { of Banten) }\end{array}$ \\
\hline 6. & $\begin{array}{l}\text { Tren jumlah nelayan } \\
\text { (The number of } \\
\text { fishermen) }\end{array}$ & $\begin{array}{l}1=\text { Turun } / \text { Decreasing } \\
2=\text { Berfluktuasi/Fluctuating } \\
3=\text { Baik/Increasing }\end{array}$ & $\begin{array}{l}\text { Jumlah nelayan selama } \\
5 \text { tahun (Number of } \\
\text { fisherman in } 5 \text { years) }\end{array}$ & $\begin{array}{l}\text { Statistik DKP Banten } \\
\text { (Statistic of Marine } \\
\text { and Fisheries Agency } \\
\text { of Banten) }\end{array}$ \\
\hline 7. & $\begin{array}{l}\text { Tren jumlah unit } \\
\text { penangkapan (The } \\
\text { number of fishing } \\
\text { units) }\end{array}$ & $\begin{array}{l}1=\text { Turun } / \text { Decreasing } \\
2=\text { Berfluktuasi/Fluctuating } \\
3=\text { Naik/Increasing }\end{array}$ & $\begin{array}{l}\text { Jumlah unit penangkapan } \\
\text { teri selama } 5 \text { tahun } \\
\text { (Number of anchovy } \\
\text { fishing unit in } 5 \text { years) }\end{array}$ & $\begin{array}{l}\text { Statistik DKP Banten } \\
\text { (Statistic of Marine } \\
\text { and Fisheries Agency } \\
\text { of Banten) }\end{array}$ \\
\hline 8. & $\begin{array}{l}\text { Usaha pengolahan } \\
\text { teri (Anchovy } \\
\text { processing business) }\end{array}$ & $\begin{array}{l}1=\text { Tidak ada usaha } \\
\text { pengolahan, pasar lokal (No } \\
\text { processing business, local } \\
\text { market) } \\
2 \text { = Terdapat usaha } \\
\text { pengolahan, pasar lokal } \\
\text { (There are processing } \\
\text { business, local market) } \\
3=\text { Terdapat usaha } \\
\text { pengolahan, pasar ekspor } \\
\text { (There are processing } \\
\text { business, an export market) }\end{array}$ & $\begin{array}{l}\text { - Usaha pengolahan } \\
\text { (Processing business) } \\
\text { - Lokasi pemasaran } \\
\text { (Marketing location) }\end{array}$ & $\begin{array}{l}\text { Observasi dan } \\
\text { wawancara } \\
\text { (Observation and } \\
\text { interview) }\end{array}$ \\
\hline
\end{tabular}

\section{HASIL DAN PEMBAHASAN}

\section{Karakteristik Sumber daya dan Usaha Kelautan dan Perikanan di Lokasi Penelitian}

Provinsi Banten memiliki wilayah laut yang cukup luas dengan total garis pantai sepanjang $866,13 \mathrm{~km}$. Perairan yang menjadi daerah penangkapan bagi nelayan-nelayan di Banten adalah Samudera Hindia, Laut Jawad dan Selat Sunda. Pertemuan dua massa air di Selat Sunda menjadikan Banten kaya akan sumber daya ikan. Produksi ikan pada tahun 2015 sebesar 55.095 ton, terdiri dari ikan pelagis kecil $17.863,5$ ton $(32 \%)$, ikan demersal 11.803 ton $(21 \%)$, ikan pelagis besar 10.588 ton $(19 \%)$, udang-udangan $5.442(10 \%)$, kekerangan 2.137 ton $(4 \%)$ dan sisanya ikan lainnya. Jenis ikan pelagis kecil yang produksinya cukup tinggi diantaranya teri, kembung, selar, dan tembang. Jenis ikan pelagis besar yang produksinya tinggi adalah tongkol dan tenggiri; sedangkan jenis ikan demersal dengan produksi tinggi adalah ikan Manyung, ikan Peperek, ikan Kurisi, dan ikan Kuniran. 


\section{Karakteristik Responden dan Gambaran Umum Lokasi Penelitian}

Responden yang terlibat dalam penelitian ini terdiri dari 18 pengelola TPI, 18 nelayan penangkap teri, 18 pengepul ikan teri dan 18 pengolah ikan teri. Semua responden berjenis kelamin laki-laki, kecuali pengepul dan pengolah ikan di Kabupaten Tangerang yang berjenis kelamin perempuan. Semua responden telah melakukan usaha di bidang perikanan lebih dari 10 tahun dan menetap di lokasi penelitian.

Provinsi Banten terletak di sisi barat Pulau Jawa, terdiri dari delapan kabupaten/kota. Enam kabupaten/kota merupakan daerah pesisir. Wilayah Kabupaten Pandeglang berada di bagian barat daya Provinsi Banten, dengan luas wilayah 2.747 $\mathrm{km}^{2}$ serta memiliki garis pantai sepanjang $307 \mathrm{~km}$. Wilayah Kabupaten Lebak berada di sisi tenggara dengan luas $3.426,56 \mathrm{~km}^{2}$ dan panjang garis pantai $91,42 \mathrm{~km}$. Wilayah Kab. Tangerang terletak di timur laut Provinsi Banten dengan luas 959,6 km² dan panjang garis pantai $54,91 \mathrm{~km}$. Wilayah Kabupaten Serang terletak di utara Provinsi Banten dengan luas $1.734 \mathrm{~km}^{2}$ dan panjang garis pantai $233 \mathrm{~km}$. Wilayah Kota Serang terletak di utara Kabupaten Serang dengan luas $266,7 \mathrm{~km}^{2}$. Wilayah Kota Cilegon terletak di barat laut Provinsi Banten dengan luas $175,5 \mathrm{~km}^{2}$. dan panjang garis pantai $25 \mathrm{~km}$.

\section{Pemilihan Lokasi Basis Perikanan Teri}

Berdasarkan hasil analisis di masing-masing kabupaten/kota diperoleh nilai LQ untuk semua kabupaten/kota pesisir $>1$, kecuali untuk Kabupaten Lebak dan Kabupaten Pandeglang, seperti yang disajikan pada Tabel 2. Hal ini menunjukkan bahwa Kabupaten Pandeglang dan Lebak bukan merupakan wilayah basis produksi teri di Provinsi
Banten. volume produksi ikan teri di Pandeglang dan Lebak masih lebih rendah dibandingkan dengan ikan pelagis lain seperti kembung, layang dan tongkol.

Produksi ikan teri di masing-masing wilayah telah mampu mendorong tumbuh dan berkembangnya usaha pengolahan teri baik untuk tujuan pasar lokal maupun nasional. Hal ini mengindikasikan bahwa ikan teri dapat menjadi komoditas utama penggerak perekonomian perikanan karena ikan teri memiliki keunggulan komparatif. Keunggulan komparatif menurut Widodo (2006) merupakan kemampuan suatu daerah untuk memproduksi komoditas atau produk yang secara relatif lebih unggul dibandingkan daerah lainnya, atau dapat dikatakan terdapat kelimpahan sumber daya yang dimiliki oleh daerah tersebut sehingga mampu mendistribusikan sumber daya tersebut ke daerah lainnya. Keunggulan komparatif menurut Mira (2013) bersifat dinamis, sehingga wilayah yang memiliki keunggulan komparatif harus mempertahankannya karena daerah lain dapat menyainginya. Hendayana (2003) menyatakan keunggulan komparatif dapat dilihat dari sisi penawaran maupun permintaan.

Berdasarkan hasil skoring dengan delapan kriteria penilaian, Kabupaten Pandeglang terpilih sebagai lokasi basis perikanan teri di Provinsi Banten (nilai skor 19), sebagaimana yang disajikan pada Tabel 3. Berdasarkan hasil skoring, maka lokasi yang potensial untuk menjadi lokasi basis perikanan teri adalah Kabupaten Pandeglang, Kabupaten Serang, Kota Serang dan Kota Cilegon. Jika dilihat dari kondisi geografis, nelayan penangkap ikan teri dari keempat lokasi tersebut memiliki daerah penangkapan di sekitar pantai hingga sisi barat Banten di perairan Selat Sunda.

Tabel 2. Nilai LQ Ikan Teri di Provinsi Banten, 2017.

Table 2. LQ Value of Anchovy Fisheries in the Banten Province, 2017.

\begin{tabular}{|c|c|c|c|c|c|c|c|}
\hline \multirow{2}{*}{$\begin{array}{l}\text { Lokasi/ } \\
\text { Location }\end{array}$} & \multicolumn{6}{|c|}{ Nilai LQ / LQ Value } & \multirow{2}{*}{$\begin{array}{l}\text { Skor I } \\
\text { Score }\end{array}$} \\
\hline & 2011 & 2012 & 2013 & 2014 & 2015 & $\begin{array}{l}\text { Rata-rata/ } \\
\text { Average }\end{array}$ & \\
\hline $\begin{array}{l}\text { Kabupaten Pandeglang (Pandeglang } \\
\text { Regency) }\end{array}$ & 0.48 & 0.45 & 0.49 & 0.55 & 1.74 & 0.74 & 2 \\
\hline Kabupaten Lebak (Lebak Regency) & 1.34 & 0.80 & 1.13 & 0.06 & 0.02 & 0.67 & 2 \\
\hline $\begin{array}{l}\text { Kabupaten Tangerang (Tangerang } \\
\text { Regency) }\end{array}$ & 1.15 & 1.30 & 1.22 & 1.58 & 0.88 & 1.23 & 3 \\
\hline Kabupaten Serang (Serang Regency) & 1.99 & 1.58 & 1.79 & 1.17 & 0.53 & 1.41 & 3 \\
\hline Kota Serang (Serang City) & 1.03 & 2.11 & 1.23 & 1.64 & 0.67 & 1.34 & 3 \\
\hline Kota Cilegon (Cilegon City) & 1.73 & 2.16 & 2.48 & 3.01 & 1.48 & 2.17 & 3 \\
\hline
\end{tabular}


Tabel 3. Hasil Skoring Pemilihan Lokasi Basis Perikanan Teri, 2017.

Table 3. The Scoring Result for Selection of Basis Location of Anchovy Fisheries, 2017.

\begin{tabular}{|c|c|c|c|c|c|c|c|c|c|c|}
\hline \multirow{2}{*}{ No. } & \multirow{2}{*}{ Lokasi/Location } & \multicolumn{8}{|c|}{ Kriteria/Criteria } & \multirow{2}{*}{$\begin{array}{l}\text { Total/ } \\
\text { Amount }\end{array}$} \\
\hline & & 1 & 2 & 3 & 4 & 5 & 6 & 7 & 8 & \\
\hline 1 & $\begin{array}{l}\text { Kabupaten Pandeglang (Pandeglang } \\
\text { Regency) }\end{array}$ & 2 & 1 & 3 & 1 & 3 & 3 & 3 & 3 & 19 \\
\hline 2 & Kabupaten Lebak (Lebak Regency) & 2 & 1 & 1 & 1 & 1 & 1 & 1 & 1 & 9 \\
\hline 3 & $\begin{array}{l}\text { Kabupaten Tangerang (Tangerang } \\
\text { Regency) }\end{array}$ & 3 & 1 & 2 & 1 & 1 & 1 & 1 & 2 & 12 \\
\hline 4 & Kabupaten Serang (Serang Regency) & 3 & 1 & 1 & 1 & 1 & 3 & 3 & 3 & 16 \\
\hline 5 & Kota Serang (Serang City) & 3 & 1 & 2 & 1 & 2 & 2 & 1 & 2 & 14 \\
\hline 6 & Kota Cilegon (Cilegon City) & 3 & 1 & 2 & 2 & 3 & 1 & 3 & 1 & 16 \\
\hline
\end{tabular}

Berdasarkan hasil survei diperoleh data dan informasi bahwa pusat pendaratan dan pengolahan teri dengan volume produksi tinggi dan kontinu sepanjang tahun berada di sepanjang pesisir Selat Sunda yaitu mulai dari di Kecamatan Panimbang, Kecamatan Citeureup hingga Kecamatan Sumur. Tingginya produksi teri di wilayah tersebut dipengaruhi oleh kondisi oseanografi di perairan Selat Sunda. Hasil penelitian Nurkhairani, Supriatna \& Susiloningtyas (2018) menunjukkan bahwa perairan Selat Sunda merupakan daerah penangkapan ikan yang potensial sepanjang tahun. Hal ini disebabkan adanya fenomena La Nina, normal maupun El Nino yang menjaga kesuburan perairan Selat Sunda sehingga menjadi feeding ground yang baik bagi berbagai spesies ikan pelagis, termasuk ikan teri. Sedangkan untuk perairan selatan Kabupaten Lebak, saat ini alat tangkap teri sudah mulai ditinggalkan karena menurut nelayan produktivitasnya berkurang. Hal ini diduga karena karakteristik osenaografi perairan selatan Jawa yang lebih dinamis, sehingga alat tangkap sulit dioperasikan dengan sempurna.

Perairan Selat Sunda yang merupakan percampuran massa air dari Samudera Hindia dan Laut Jawa menyebabkan perairan ini memiliki produktivitas yang cukup tinggi, namun juga memiliki dinamika oseanografi yang cukup tinggi pula. Hal ini menyebabkan produktivitas ikan teri di daerah Pandeglang merupakan yang tertinggi di Provinsi Banten. Kesuburan perairan Selat Sunda dipengaruhi oleh fenomena upwelling yang terjadi pada periode tertentu. Kejadian upwelling di perairan Selat Sunda telah dimulai pada bulan Juni dan terjadi dua kali dalam satu tahun, yaitu pada musim timur dan musim peralihan (Muripto, Manurung \& Rahadian, 2000; Amri, Manurung \& Siregar, 2007). Peningkatan produktivitas penangkapan ikan pelagis berkorelasi dengan peningkatan kesuburan perairan diakibatkan oleh upwelling yang terjadi di Selat Sunda (Amri, Priatna \& Suprapto, 2014).

Kelimpahan sumberdaya ikan pelagis kecil akan berbeda secara spasial pada setiap wilayah perairan. Hal ini disebabkan karena jenis sumberdaya ikan pelagis kecil cukup sensitif terhadap dinamika atau perubahan lingkungan perairan yang umumnya variatif pada wilayah dan periode waktu yang berbeda (Simbolon, 2011). Hasil penelitian Riyanti (2017) juga menunjukkan bahwa aktivitas industri yang berlangsung di pesisir Bojonegara memiliki dampak negatif terhadap aktivitas perikanan teri yang berbasis di Tempat Pelelangan Ikan (TPI) Kepuh Provinsi Banten. Alat tangkap payang yang dulunya beroperasi di perairan Bojonegara kemudian bergeser operasinya ke perairan Pulau Panjang. Hal tersebut terjadi karena perairan Bojonegara telah tercemar perairannya, sehingga mengakibatkan perubahan habitat ikan teri dan daerah penangkapan alat tangkap payang.

Selain itu perubahan musim, seperti musim barat dan musim timur, juga mempengaruhi lokasi penangkapan alat tangkap bagan, khususnya bagan tancap. Bagan tancap umumnya melakukan perpindahan lokasi fishing ground sebanyak dua kali dalam setahun, setelah musim barat (periode Maret-Juli) dan setelah musim timur (periode Agustus-November). Namun, masih diperlukan riset lanjutan terkait perubahan lokasi daerah penangkapan bagan ini. Musim penangkapan ikan teri di Provinsi Banten untuk wilayah perairan utara Jawa terjadi pada bulan Februari-April, Juni dan Oktober; wilayah perairan Selat Sunda terjadi pada bulan April, Juni-Agustus; dan perairan Selatan Jawa terjadi pada bulan Januari-Maret dan Juli-September (Irnawati, Surilayani, Susanto, Munandar \& Rahmawati, 2018). 


\section{Jalur Pemasaran dan Distribusi Ikan Teri}

Pendistribusian ikan teri masih dipengaruhi oleh fluktuasi hasil tangkapan karena apabila bahan baku menurun maka harga ikan teri akan naik. Namun untuk ikan teri nasi, meskipun bahan baku utamanya melimpah (pada saat musim ikan), jenis teri ini memiliki harga jual yang cukup tinggi dibandingkan jenis ikan teri lainnya. Panjang pendeknya jalur distribusi hasil tangkapan ikan teri juga berpengaruh terhadap biaya pendistribusian yang mengakibatkan harga ikan teri menjadi sangat mahal. Selain itu, panjang pendeknya rantai distribusi juga akan berpengaruh terhadap keuntungan usaha yang diperoleh (Karim, 2014).

Jalur distribusi ikan teri yang terdapat di Banten adalah jenis saluran tingkat dua dan saluran tingkat tiga. Kotler \& Amstrong (2004) menyatakan saluran tingkat dua (produsen-grosir-pengecerkonsumen) yang mempunyai dua perantara penjualan. Dalam pasar konsumen mereka merupakan pedagang besar (grosir) dan sekaligus pengecer. Saluran tingkat tiga (produsen-grosirdistributor-pengecer--konsumen) yang mempunyai tiga perantara penjualan, seperti yang disajikan pada Gambar 2. Menurut Hanafiah \& Saepudin (2006), panjang pendeknya saluran distribusi hasil perikanan tergantung beberapa faktor, diantaranya jarak antar produsen dan konsumen, cepat tidaknya produk rusah, skala produksi dan posisi keuangan pengusaha.

Produsen biasanya menjual langsung kepada grosir kemudian grosir menjual ke distributor dan seterusnya. Kemudian para pembeli ada yang langsung datang ke lokasi pengolahan dan membawa transportasi atau pengangkutan ikan teri sendiri. Ada juga yang diantar oleh produsen ketempat para pembeli. Harga teri yang diantar dari produsen kepada grosir, distributor, pedagang pengecer ditambah biaya angkut dan juga diambil keuntungan dari proses pendistribusiannya.
Aktivitas perikanan bagan di Kota Cilegon dan Kabupaten Lebak memang ada, namun jumlah unit penangkapannya sangat kecil dan tidak berkembang dengan baik. Sedangkan untuk perikanan teri di Kota Serang yang berbasis di PPN Karangantu biasanya dijual dalam bentuk segar atau hanya mengolah ikan teri ukuran besar, untuk teri nasi biasanya dijual ke pengepul di Bojonegara atau Pulau Panjang. Oleh karena itu dalam penjabaran mengenai jalur pemasaran dan distribusi ikan teri hanya mencakup wilayah Kabupaten Pandeglang, Kabupaten Serang, dan Kabupaten Tangerang. Jalur pemasaran ikan teri dari ketiga lokasi tersebut disajikan pada Gambar 3.

\section{Kabupaten Pandeglang}

Perikanan teri di Kabupaten Pandeglang berbasis di Panimbang, Citeureup dan Sumur. Ketiga lokasi tersebut menyumbang produksi teri yang cukup tinggi dan menjadikan Kabupaten Pandeglang sebagai produsen teri terbesar di Provinsi Banten. Ikan teri kering di Panimbang umumnya tidak asin dan tidak tawar. Terdapat tiga jenis ikan teri di sini, yaitu ikan teri jengki, teri galagah dan teri nasi. Teri jengki umumnya dipasarkan di pasar lokal hingga ke Serang dan Tangerang, sedangkan teri nasi dipasarkan ke luar provinsi karena nilai ekonomisnya cukup tinggi. Ikan teri yang telah diolah dan dikeringkan biasanya dijual hingga ke Bogor dan Jakarta. Meskipun ada juga yang dijual di pasar lokal, namun jumlahnya biasanya tidak terlalu banyak. Pemasaran ikan teri di Jakarta biasanya masuk ke perusahaan dagang, untuk kemudian diekspor ke luar negeri.

Perikanan teri di Citeureup dilakukan dengan alat tangkap bagan. Ikan teri hasil tangkapan nelayan Citeureup tidak didaratkan ke TPI Citeureup namun didaratkan di Panimbang. Ikan teri biasanya dijemput dan diolah di sana. Ikan teri di daerah Sumur ditangkap dengan alat tangkap

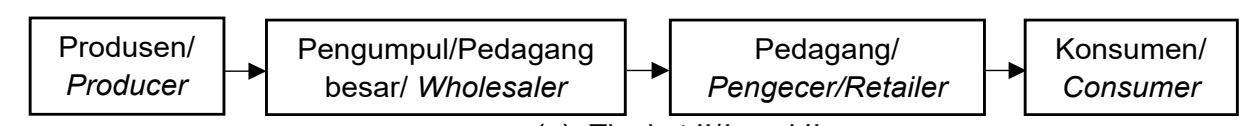

(a) Tingkat II/Level II

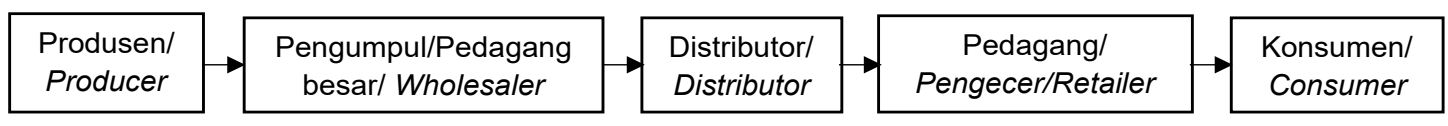

(b) Tingkat III/Level III

Gambar 2. Jalur Pemasaran Ikan Teri di Provinsi Banten Tahun 2017. Picture 2. Anchovy Marketing Channel in The Banten Province in 2017. 


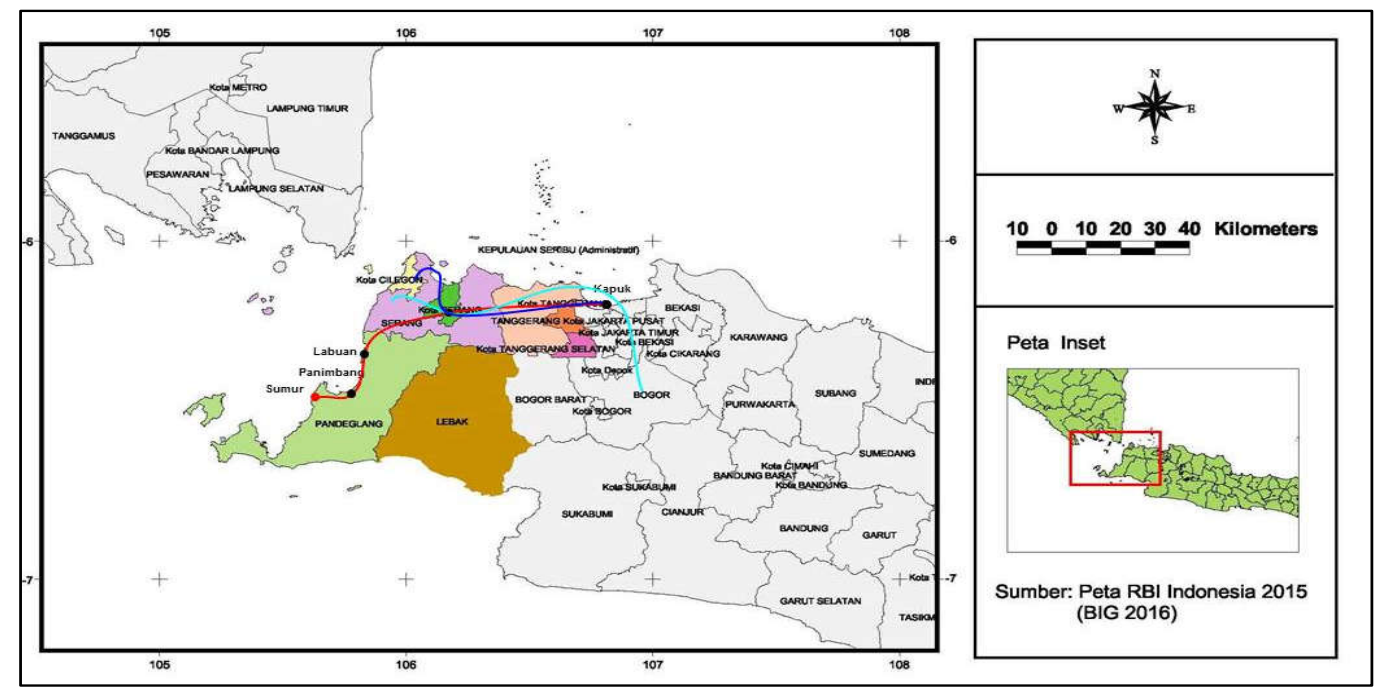

Gambar 3. Jalur Pemasaran Ikan Teri di Provinsi Banten.

Picture 3. Anchovy Marketing Channel in The Banten Province.

Sumber: Hasil penelitian dan pengolahan data, 2017/Source: Research results and data processing, 2017

bagan perahu (terdiri dari bagan perahu, bagan congkel dan bagan jerigen) dan bagan tancap. Setiap pengolah umumnya memiliki lebih dari satu unit alat tangkap. Pengolah juga memiliki kapal yang berfungsi untuk menarik bagan, kapal untuk mengambil ikan dan kapal untuk mengantar jemput nelayan. Hal ini menjadikan perikanan teri di daerah Sumur menjadi yang terbesar dan termaju diantara semua lokasi yang ada di Provinsi Banten.

Ikan teri nasi kering biasanya dikirim ke daerah Kapuk atau Muara Angke Jakarta, terdapat beberapa pengumpul besar ikan teri. Dari Jakarta biasanya ikan-ikan teri kering ini ada yang dijual di kota-kota besar yang ada di Pulau Jawa dan juga diekspor ke Korea. Ikan teri dari Sumur, Citereup dan Panimbang dipasarkan untuk pasar lokal Banten meliputi wilayah Labuan dan Serang. Sementara itu untuk pasar di luar Banten, umumnya pemasaran dilakukan di wilayah Kapuk Jakarta Utara. Setelah dijual kepada penampung besar di Jakarta Utara, ikan teri selanjutnya dipasarkan ke berbagai wilayah di tanah air atau diekspor.

\section{Kabupaten Tangerang}

Perikanan teri di Kabupaten Tangerang berbasis di TPI Cituis. Para pengolah teri nasi di Tangerang sudah banyak yang tutup karena menurut mereka memerlukan banyak tenaga dan waktu untuk proses pengolahan, namun ikan teri yang didaratkan sedikit. Pengepul ikan asin dari wilayah ini biasa memasarkan produknya ke daerah Kapuk serta pasar tradisional dan modern di sekitar Tangerang. Produk ikan asin yang dikirim ke pasar modern sudah memiliki kemasan yang baik. Daerah pemasaran yang lainnya yaitu Serang, Anyer dan Bogor.

\section{Kabupaten Serang}

Perikanan teri di Kabupaten Serang berbasis di Bojonegara. Pengolahan ikan teri juga dijumpai di Grenyang dan Pulau Panjang. Para pengolah biasanya juga melayani permintaan ikan teri kering tawar dan asin. Ikan teri yang telah diolah dijual di Pasar Bojonegoro, Serang, Cilegon dan juga dikirim ke perusahaan di Jakarta untuk diekspor ke Korea dan Jepang. Namun permintaan ekspor sudah mengalami penurunan yang cukup drastis sejak 2010, karena hanya Jepang saja saat ini yang permintaan terhadap ikan teri masih tinggi.

Menurut hasil wawancara dengan $\mathrm{H}$. Sujai selaku pelaku usaha pengolahan ikan teri yang telah 23 tahun melakukan usaha, musim teri di perairan Bojonegara dan Teluk Banten berkisar bulan Maret-Agustus. Namun saat ini hasil tangkapannya sudah jauh menurun, diantaranya diduga karena cuaca yang sering tidak menentu dan kerusakan laut akibat adanya bahan-bahan limbah buangan industri dan kapal-kapal tongkang. Hasil penelitian Riyanti (2017) juga menunjukkan perairan Bojonegara telah mengalami pencemaran akibat buangan limbah industri yang mengakibatkan beralihnya kegiatan penangkapan payang ke sekitar perairan Pulau Panjang.

Jalur pemasaran ikan teri dari yang diuraikan diatas masih dapat dikatakan belum efisien karena 
masih panjang dan banyak pedagang perantara yang terlibat. Menurut Nuriati (2017), belum efisiennya saluran (jalur) pemasaran karena kegiatan pemasaran tidak dilakukan oleh satu tangan tetapi oleh beberapa perantara, baik skala besar maupun sakla kecil, sehingga membentuk mata rantai yang panjang. Johanson (2013) juga menyatakan pemasaran yang efektif diindikasikan dengan pola saluran distribusi yang efisien, antara lain relatif sedikitnya keterlibatan pedagang perantara dan jalur distribusi yang relatif pendek.

\section{KESIMPULAN DAN REKOMENDASI KEBIJAKAN}

\section{Kesimpulan}

Lokasi basis perikanan teri di Provinsi Banten berada di Kabupaten Pandeglang dengan wilayah produksi dan pengolahan utama di Sumur, Citeureup dan Panimbang. Lokasi yang potensial selain Pandeglang adalah Kabupaten Serang, Kota Serang, dan Kota Cilegon. Jalur pemasaran ikan teri terdiri atas jalur pemasaran tingkat dua dan tingkat tiga. Ikan teri didistribusikan dari pasar lokal hingga ke luar provinsi dan ekspor.

\section{Rekomendasi Kebijakan}

Produk olahan dari ikan teri dapat dikembangkan untuk memenuhi ketersediaan bahan pangan, sumber kalsium, serta sumber protein ikan yang sehat, aman dan berkualitas. Inovasi dan kreativitas diperlukan untuk menciptakan variasi produk olahan dengan nilai tambah dan nilai guna yang lebih tinggi. Pengembangan jejaring pemasaran melalui pemanfaatan teknologi informasi diharapkan mempercepat sirkulasi produk dan kepastian harga.

\section{UCAPAN TERIMA KASIH}

Tim penulis mengucapkan terima kasih kepada Islamic Development Bank (IsDB) yang telah membiayai penelitian ini melalui Hibah Penelitian UNTIRTA Tahun 2017 (The Development of Sultan Ageng Tirtayasa University as Center of Excellence in Food Security for Nation Competitiveness). Kami juga mengucapkan terima kasih kepada pada dosen dan mahasiswa Jurusan Perikanan UNTIRTA yang telah membantu dan memberikan dukungan sejak awal hingga selesainya kegiatan penelitian ini.

\section{PERNYATAAN KONTRIBUSI PENULIS}

Dengan ini kami menyatakan bahwa kontribusi masing-masing penulis terhadap pembuatan karya tulis adalah: Ririn Irnawati sebagai kontributor utama, Dini Surilayani, Adi Susanto, Ani Rahmawati, Aris Munandar, Hery Sutrawan Nurdin dan Ratu Sari Mardiah sebagai kontributor anggota. Penulis menyatakan bahwa telah melampirkan surat pernyataan kontribusi penulis.

\section{DAFTAR PUSTAKA}

Akbar, M.Y., Diansyah, G. \& Isnaini. (2016). Deteksi Cemaran Bakteri Salmonella sp. Pada Ikan Teri (Stolephorus spp.) Hasil Perikanan di Perairan Sungsang Kabupaten Banyuasin Sumatera Selatan. Maspari Journal, 8(1), 25-30.

Amri, K., Manurung, D., \& Siregar, V.P. (2007). Dinamika Kondisi Oseanografi Musiman Perairan Selat Sunda dari Analisis Data Multitemporal. Jurnal Penelitian Perikanan Indonesia, 13(3), 191-199.

Amri, K., Prianta, A., \& Suprapto. (2014). Karakteristik Oseanografi dan Kelimpahan Fitoplankton di Perairan Selat Sunda Pada Musim Timur. Bawal, 6(1), 11-20.

[DKP] Dinas Kelautan dan Perikanan. (2017). Laporan Statistik Perikanan Provinsi Banten Tahun 2015. Serang: Dinas Kelautan dan Perikanan Provinsi Banten.

[DKP] Dinas Kelautan dan Perikanan. (2018). Kelautan Perikanan Provinsi Banten dalam Angka Tahun 2018. Serang: Dinas Kelautan dan Perikanan Provinsi Banten.

Hanafiah, A.M. \& Saefuddin, A.M. (2006). Tata Niaga Hasil Perikanan. Jakarta: UIP.

Hendayana, R. (2003). Aplikasi Metode Location Quotient (LQ) dalam Penentuan Komoditas Unggulan Nasional. Informatika Pertanian, 12, 1-21.

Husein, I. G., Sunindyo, W.D., Bahawares, R., Nainggolan, Y., \& Akbar, S. (2015). Open Data Strategy for Enhancing the Productivity and Competitiveness of Fishery SMEs in Indonesia. Proceeding: 2015 August 10-11; Indonesia. Bali: The 5th International Conference on Electrical Engineering and Informatics. p.490-495.

Irnawati, R., Mustahal, Susanto, A., \& Syabana, M.A. (2014). Model Pengelolaan Kawasan Pesisir untuk Kegiatan Penangkapan dan Budidaya Laut di Pulau Panjang Kabupaten Serang Banten. Jurnal IImu Pertanian dan Perikanan, 3(1), 55-62. 
Irnawati, R., Mustahal, Susanto, A., \& Syabana, M.A. (2015). Model Pengelolaan Kawasan Pesisir Berbasis Ekosistem untuk Menunjang Produksi Karagenan Sebagai Komoditas Unggulan di Pulau Panjang [Laporan Tahun III]. Serang: Universitas Sultan Ageng Tirtayasa.

Irnawati, R., Surilayani, D., Susanto, A., Munandar, A., \& Rahmawati, A. (2018). Potential Yield and Fishing Season of Anchovy (Stolephorus sp.) in Banten, Indonesia. AACL Bioflux, 11, 804-809.

Johanson, D. (2013). Analisis Efisiensi Pola Distribusi Hasil Penangkapan Ikan Nelayan Kecamatan Kahayan Kuala Kabupaten Pulang Pisau. Jurnal Sains Manajemen, 1(1), 96-109.

Karim, M. (2014). Gambaran Umum Agribisnis Ikan Teri di Kabupaten Barru Sulawesi Selatan. Jurnal Balik Diwa, 5(1), 54-61.

Kotler, P. \& Amstronng, G. (2004). Dasar-Dasar Pemasaran Jilid I. Jakarta: Indeks. 463 hlm.

Laisa, D.D., Sayekti, W.D. \& Nugraha, A. (2013). Analisis Harga Pokok Produksi dan Strategi Pengembangan Industri Pengolahan Ikan Teri Nasi Kering di Pulau Pasaran Kecamatan Teluk Betung Barat Kota Bandar Lampung. Jurnal IImu-IImu Agribisnis, 1(2), 111-117.

Lubis, E. (2011). Kajian Peran Strategis Pelabuhan Perikanan Terhadap Pengembangan Perikanan Laut. AKUATIK-Jurnal Sumberdaya Perairan, 5(2), 1-7.

Mira. (2013). Keunggulan Subsektor Perikanan dan Pariwisata Bahari Dalam Struktur Perekonomian Wilayah Pulau-Pulau Kecil. Jurnal Sosial Ekonomi Kelautan dan Perikanan, 8(2), 145-156.

Muripto, I., Manurung, D. \& Rahadian. (2000). Oceanographic Features that Define the Sunda Strait Upwelling Related to Hot Spot Area. The Proceedings of the JSP-DGHE International Symposium on Fisheries Science in Tropical Area. Bogor. Indonesia. Hal: 23-31.

Nuriati, N.K. (2017). Analisis Efisiensi Saluran Pemasaran Ikan Tongkol Hasil Tangkapan Nelayan di Desa Seraya Timur Kecamatan Karangasen. Jurnal Pendidikan Ekonomi, 10(2), 1-11.

Nurkhairani, Y., Supriatna \& Susiloningtyas, D. (2018). Wilayah Potensi Ikan Pelagis pada Variasi Kejadian ENSO dan normal di Selat Sunda. Jurnal Geografi Lingkungan Tropik, 2(1), 52-63.

Riyanti, T. (2017). Pengaruh Buangan Limbah Industri Terhadap Perubahan Daerah Penangkapan Alat Tangkap Payang di Perairan Bojonegoro Provinsi Banten [Skripsi]. Serang: Jurusan Perikanan, Fakultas Pertanian, Universitas Sultan Ageng Tirtayasa.
Rahmawati, W., Suryono, A. \& Siswidiyanto. (2014). Kajian Pengembangan Pelabuhan Perikanan Dalam Rencana Penyerapan Tenaga Kerja Masyarakat Pesisir (Studi Pada Kantor Pelabuhan Perikanan Nusantara Brondong Kabupaten Lamongan). Jurnal Administrasi Publik, 2(2), 367-373.

Safruddin, Zainuddin, M. \& Tresnati, J. (2014). Dinamika Perubahan Suhu dan Klorofil-a Terhadap Distribusi Ikan Teri (Stolephorus spp.) di Perairan Spermonde, Pangkep. Jurnal IPTEKS PSP, 1(1), 11-19.

Simbolon, D. (2011). Bioekologi dan Dinamika Daerah Penangkapan Ikan. Bogor: Departemen Pemanfaatan Sumberdaya Ikan, Fakultas Perikanan dan IImu Kelautan, Institut Pertanian Bogor.

Sirait, M. (2013). Kajian Pengembangan Perikanan Berbasis Komoditas Unggulan di Kabupaten Muna. Jurnal Kelautan, 6(2), 150-155.

Susanto, A. (2015). Mapping of light Fishing Ground Using Viirs Day-Night Band Data in Pandeglang Water Banten Province. Depik, 4(2), 69-78. DOI: 10.13170/depik.4.2.2454.

Susanto, A., Irnawati, R., Mustahal \& Syabana, M.A. (2017). Fishing Efficiency of LED Lamps for Fixed Lift Net Fisheries in Banten Bay Indonesia. Turkish Journal of Fisheries and Aquatic Sciences, 17, 283-291. DOI: 10.4194/1303-2712v17_2_07.

Sutono, D. \& Susanto, A. (2016). Pemanfaatan Sumberdaya Ikan Teri di Perairan Pantai Tegal. Jurnal Perikanan dan Kelautan, 6(2), 104-115.

Widodo, T. (2006). Perencanaan Pembangunan, Aplikasi Komputer (Era Otonomi Daerah). Yogyakarta: Penerbit UPP STIM YKPN. 